\title{
Erratum to: Settlement patterns of mountainous half-filled and half-cut widened subgrade with retaining wall
}

\author{
FU Yong-guo ${ }^{1,2,3}$ iD https://orcid.org/oooo-00o3-1416-5992; e-mail: 809107486@qq.com \\ JIANG Xin 1,2,3* iD https://orcid.org/oooo-0002-3044-5495; \e-mail: xjiang01@163.com, xjiang01@swjtu.edu.cn \\ GU Han-yan 1,2,3 iDhttps://orcid.org/oooo-ooo3-2881-6282; e-mail: 893634386@qq.com \\ QIU Yan-jun 1,2,3 iD https://orcid.org/oooo-0oo2-2250-5363; e-mail: publicqiu@vip.163.com \\ *Corresponding author \\ 1 School of Civil Engineering, Southwest Jiaotong University, Chengdu 610031, China \\ 2 MOE Key Laboratory of High-speed Railway Engineering, Southwest Jiaotong University, Chengdu 61oo31, China \\ 3 Highway Engineering Key Laboratory of Sichuan Province, Southwest Jiaotong University, Chengdu 610o31, China \\ Citation: Fu YG, Jiang X, Gu HY, Qiu YJ (2021) Erratum to: Settlement patterns of mountainous half-filled and half-cut \\ widened subgrade with retaining wall. Journal of Mountain Science 18(12). https://doi.org/10.1007/s11629-020-6267-o
}

(C) Science Press, Institute of Mountain Hazards and Environment, CAS and Springer-Verlag GmbH Germany, part of Springer Nature 2021

Erratum to: J. Mt. Sci. (2021) 18(10): 2791-2802

https://doi.org/10.1007/s11629-020-6551-z

The numbers of four figures in the figure captions are wrong.

On Page 2797, the figure's number in the figure caption should be Fig. 6.

On Page 2798, the figure's number in the figure caption should be Fig. 7.

On Page 2799, the figure's number in the figure caption should be Fig. 8.

On Page 2801, the figure's number in the figure caption should be Fig. 11. 